\title{
Foresight in Higher Education Institutions: Evidence from Poland
}

\author{
Joanna Ejdys \\ Professor, j.ejdys@pb.edu.pl \\ Alicja Gudanowska \\ Assistant Professor, a.gudanowska@pb.edu.pl \\ Katarzyna Halicka \\ Professor, k.halicka@pb.edu.pl \\ Anna Kononiuk \\ Assistant Professor, a.kononiuk@pb.edu.pl \\ Andrzej Magruk \\ Assistant Professor, a.magruk@pb.edu.pl \\ Joanicjusz Nazarko \\ Full Professor, j.nazarko@pb.edu.pl \\ Łukasz Nazarko \\ Assistant Professor, 1.nazarko@pb.edu.pl \\ Danuta Szpilko \\ Assistant Professor, d.szpilko@pb.edu.pl \\ Urszula Widelska \\ Assistant Professor, u.widelska@pb.edu.pl
}

Bialystok University of Technology, 45A, Wiejska Street, 15-351 Bialystok, Poland

\begin{abstract}
$\mathrm{T}$

The rapid transformation of the socioeconomic, political, and technological context predetermines changes in the expectations for higher education institutions which face numerous profound challenges. In order to survive and develop under changing conditions, universities need to drastically rethink their development strategies. This paper substantiates the effectiveness of using foresight for these purposes, which is confirmed by the experience of a project on the development of scenarios for the Faculty

of Engineering Management (FEM) at Bialystok Technical University (Poland) for the period up to 2035. This enquiry has resulted in compiling four alternative visions for FEM. By analyzing them one can gain valuable knowledge on both preferable and lessfavored alternatives, which on the one hand suggest which actions may lead to their realization, and on the other, indicate specific actions that may lead to the abandonment of undesirable paths in favor of the most conducive vision.
\end{abstract}

Keywords: foresight; scenarios;

higher education institution; strategy;

management; engineering.
Citation: Ejdys J., Gudanowska A., Halicka K., Kononiuk A., Magruk A., Nazarko J., Nazarko Ł., Szpilko D., Widelska U. (2019) Foresight in Higher Education Institutions: Evidence from Poland. Foresight and STI Governance, vol. 13, no 1, pp. 77-89.

DOI: 10.17323/2500-2597.2019.1.77.89 
A rapidly changing and turbulent environment as well as the complex conditions of socioeconomic development translate into a high level of uncertainty in the functioning of both private and public entities. Higher education institutions (HEI) are among those entities that must adapt to the changes in order to achieve their goals and to perform effectively [Clark, 1998]. The rapidly changing technical and socioeconomic environment creates new challenges for the management of organizations [Jamali, 2005]. The shift towards the knowledge economy [Peters, Humes, 2003] and political transformations as well as the popularity of higher education is a source of many challenges for the universities all over the world. The changing social, economic, cultural, and legal conditions of the European higher education system affect the management and funding systems of universities [Clark, 1998; Shattock, 2009; Maassen, 2008; Paradeise et al., 2009; Stock, 2008]. Universities will be able to maintain their proper place and role in society only if they are able to adapt to emerging challenges [van Vught, 1999] and manage a complex network of stakeholders [Labanauskis, Ginevičius, 2017].

In UNESCO's World Declaration on Higher Education for the Twenty-First Century: Vision and Action, a number of challenges were posed to higher education institutions in all countries including "financing, equity of conditions at access to and during the course of studies, improved staff development, skills-based training, enhancement and preservation of the quality in teaching, research and services, relevance of programmes, employability of graduates, establishment of efficient co-operation agreements and equitable access to the benefits of international co-operation. At the same time, higher education is being challenged by new opportunities relating to technologies that are improving the ways in which knowledge can be produced, managed, disseminated, accessed and controlled." [UNESCO, 1998]. Even though twenty years have passed since the declaration was adopted, the challenges indicated in the aforementioned documents remain important and valid. They could be synthesized into three imperatives or dilemmas: 1) HEIs must prepare students for life and work in a rapidly changing world; 2) HEIs must strike the right balance between cooperation and competition as well as between mass education and elitist excellence; 3 ) Which public policy and which mode of governance is fitting for today's higher education? [Curaj et al., 2010]. In response, there is a tendency at HEIs to enhance content mobility, distributed learning, tailored programs, high-tech media centers and virtual learning communities [Cunningham et al., 2000]. National policymakers strive to ensure this transformation by implementing higher education reform.

The Minister of Science and Higher Education in Poland has acknowledged that science and higher education face many new challenges. They include demographic decline, the adaptation to new technologies, international competition for funds for research and competition between universities for foreign students. To adapt to these challenges, the Ministerial Programme for the Development of Higher Education and Science for the Years 2015-2030 was adopted in 2015. Justifying the need for the change, the Minister pointed out that "We want (...) to contribute to the better use of the potential of universities and science for the development of social and economic life in the country and to lead the way for the development of a strong international position of Polish universities".

The program was structured around four main goals: (i) increasing the quality of the higher education system and adapting it to social and economic needs; (II) improving the quality of research conducted at Polish scientific institutions; (III) the improvement of the function of the higher education and research system in Poland through changes in the areas of organization, management and financing; (IV) increasing the impact upon the social, economic, and international environment [MSHE, 2015].

In accordance with the main objectives of the program, a reform of the higher education system was conducted in Poland, which resulted in the adoption of a law on higher education and science ${ }^{1}$. The adoption of the law was preceded by several months of public consultations: conferences and meetings that indicated the intention to implement a participatory model of introducing legislative changes where a wide range of academic staff and students were engaged in debating the projected changes [Kwiek, 2017]. The reform introduces a number of changes related to the functioning of universities: their funding, organizational structure, research and development, university research excellence evaluation, and internationalization.

The transformation of the higher education system in Poland, strengthened by a wide array of economic, social, and technological factors, has a significant impact upon the functioning of universities in Poland. It has become increasingly difficult to adopt a strategy that allows universities to succeed. The features of a successful strategy of a HEI should - in the authors' opinion - set up and introduce universities to completely new, future-oriented development paths. Only original strategic concepts make it possible to cope with the changes and lead the university away from the tendency to duplicate past solutions. Consistent, logical, and long-term strategy responding to signals from the environment will allow the university to undertake actions enabling more effective and efficient action. At the same time, universities with long-term strategies may be more "future-proof", that is, able to withstand unexpected changes and the occasional chaotic steps of decision-makers.

One of the instruments that enable universities to develop their long-term strategies is foresight, which has been widely used in the processes of national, regional, and corporate development [Nazarko et al., 2013;

Ustawa z dnia 20 lipca 2018 r. Prawo o szkolnictwie wyższym i nauce [Law on Higher Eduction and Science, 20 June 2018 ]. 
SUPPLY SIDE

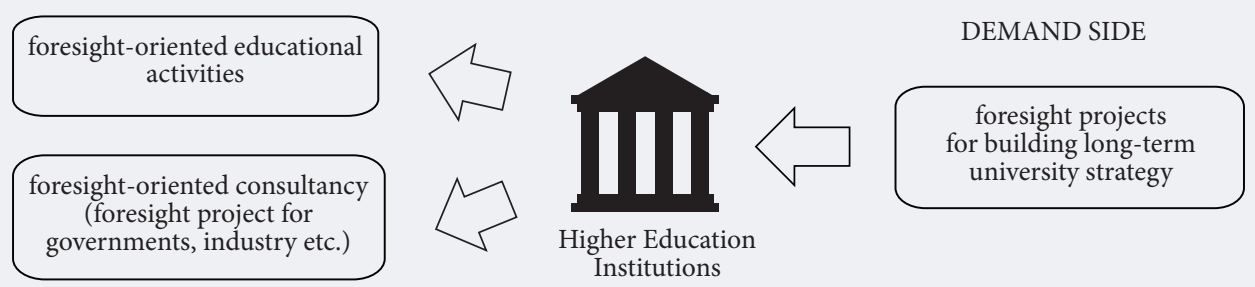

Source: compiled by the authors.

Nazarko, 2013; Ejdys, 2013, 2014; Ejdys, Nazarko, 2014; Szpilko, 2014, Kononiuk et al., 2017a]. Foresight, used since the 1970s, integrates three processes: strategic planning, the development of thematic policies (for example, innovative, technological, scientific, regional), and the development of futures studies [SzczebiotKnoblauch, 2013].

HEIs are a special type of strategic actor [Whitley, 2008]. Despite their limitations, they are able to creatively apply strategic foresight instruments to envision and shape their future [Ughetto, 2007]. The purpose of this article is to carry out an overview of the role of foresight in higher education and to present a case study of foresight applied to strategy development at a higher education institution. The case study describes a foresight process conducted at the Faculty of Engineering Management of Bialystok University of Technology in Poland. The aim of the process was to build alternative development scenarios for the faculty in the period until 2035 with the active participation of the employees and students. The formulated scenarios are the basis for the development of FEM's strategy as well as the framework for the construction of the Faculty's development roadmaps. The detailed objectives include: (i) the identification of factors affecting the development of FEM and (ii) staff engagement in the process of building a vision for FEM.

The authors start by reviewing the literature on foresight used by HEIs. The conducted literature review allowed us to distinguish three types of activities in which HEI can engage in the field of foresight: (i) foresight-oriented educational activities (supply side), (ii) foresight-oriented consultancy offered by universities (supply side), and (iii) foresight projects for building long-term university strategy (demand side) (Figure 1). A study of best practices in foresight projects as well as the practical needs of FEM in the context of building a long-term strategy served as the basis for the formulation of the research methodology. Next, results of the foresight study are presented. Finally our section on conclusions and discussion summarizes the findings and briefly explains the limitations of this study and implications for the future research.
The literature review and practical experience of the authors as academics have allowed for formulating the following three hypotheses.

Hypothesis 1: Scenario method is an informative tool for the process of developing HEI strategy.

Hypothesis 2: Economic factors are most important for the development of the FEM ecosystem

Hypothesis 3: Legal and institutional factors are the most important source of uncertainty in the development of the FEM ecosystem.

The first hypothesis is a general one and it applies to the informative features of scenario method. The authors have assumed that the informative dimension of the scenario method for HEI institutions could be achieved by the enrichment of scenario method usting a STEEPVL analysis.

The second hypothesis refers to the importance of economic factors in the development of the FEM ecosystem. The formulation of this hypothesis seemed vital because of the severe underfunding of HEI coupled with the low level of R\&D financing in Poland compared with other European countries.

The rationale for the formulation of the third hypothesis stemmed from the reform of the Polish higher education system that was initiated in February 2016. At the time of this foresight study at FEM, the law on higher education was still underway. Legislative changes related to the functioning of universities such as their funding, university excellence evaluation, or the changes in their organizational structures were yet to be defined.

\section{Examples of HEI Involvement in Foresight Activities}

Foresight research may be organized in many ways. It could be run at the international, national, regional, or organizational level. Universities may be involved in the foresight activities as the project partners or beneficiaries. They also provide educational offerings (at the bachelor, master, and $\mathrm{PhD}$ levels) in the scope of foresight, futures, or future-oriented strategizing. 
Figure 2. A General Typology of University Foresight

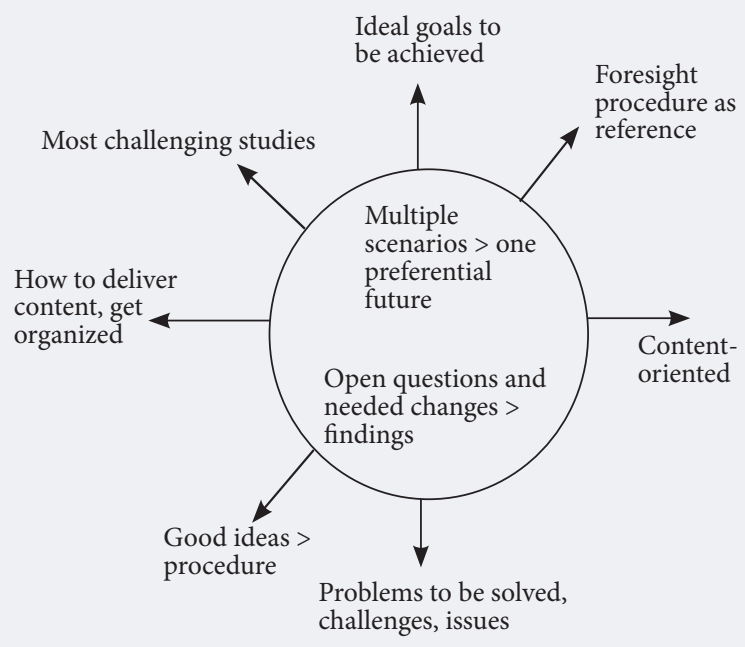

Notee: «>» means here «more important than».

Source: [Curaj et al., 2010, p. 43].

The underlying question concerns the key foresight competences that universities could teach and whether or not they are capable of educating professional futurists [Hines et al., 2017]. An extensive analysis of foresight curricula offered by various universities was carried out within the ERASMUS+ project: "Becoming Future-Oriented Entrepreneurs at universities and companies - BeFORE", which is co-funded under the Knowledge Alliance scheme. The project takes on the challenge of transforming university entrepreneurship education, company training, and business practice. It brings together academic, research, and business partners, who anticipate the development and publication of the original educational offering, which would provide Futures Literate Individuals with an improved capacity for dealing with possible futures [Kononiuk et al., 2017b]. The foresight courses offered by the universities were reviewed. The names of the universities and the courses are presented in Table 1.

The offered courses analyzed within the beFORE project demonstrate a range of understanding of foresight research, its application, and potential beneficiaries. It should be noted that they target a variety of professionals and disciplines. For example, Bialystok University of Technology aims their course of a study at professionals in the field of management, logistics, and services. Courses led by the German universities are directed towards students of urban planning, architecture, or engineers [Kononiuk et al., 2017b].

The proactive role of foresight research is emphasized by the courses such as Future-Oriented Strategizing (Aarhus University) or Design Your Future: Design Innovation for Global Teams (Stanford University). Some of the courses present foresight research in broader context such as Futurism and Business: Dealing with
Figure 3. A General Framework of University Foresight

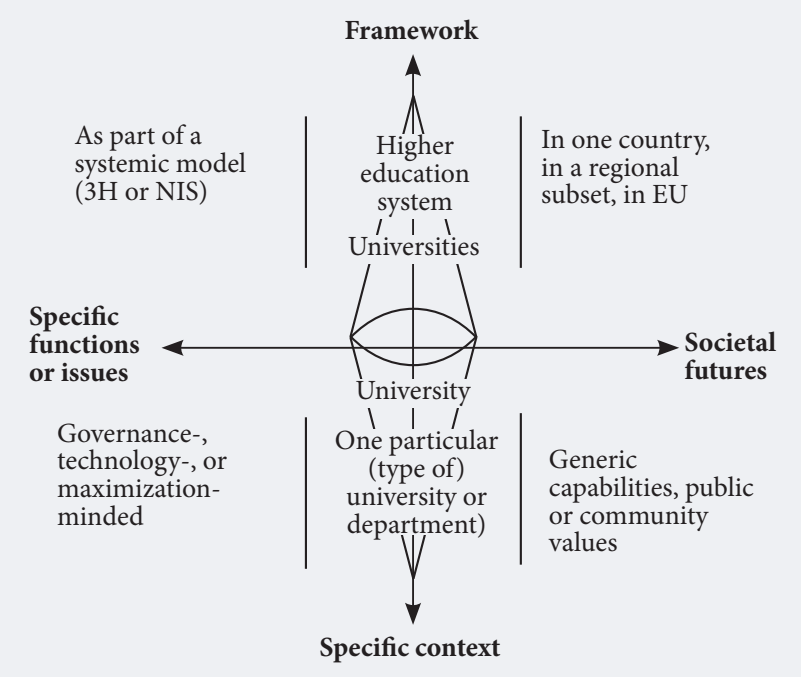

Source: [Curaj et al., 2010, p. 44].

Complexity (University of Stellenbosch (Business School)) or narrow a subject by limiting the foresight study to a particular region [Kononiuk et al., 2017b].

Bachelor's, Master's, and PhD courses in the foresight field concentrate on the general context of the field including its philosophical dimension, methodological assumptions, and include a strong methodological component and highlight the most popular set of foresight methods such as trend scanning, scenario building and strategizing, or the background of foresight research such as systems or complexity theories. A more detailed analysis of the offered curricula revealed that the courses focus on enhancing strategic management, competencies for the assessment of project management and innovation management. They value leadership and change management [Kononiuk et al., 2017b]. The potential for using foresight to reflect and deliberate upon the future of HEIs has been noted by the authors of a manual (blueprint) for organizing foresight at universities [Curaj et al., 2010]. They also refer to five cases of university foresight from Ireland, Malaysia, Turkey, Canada, and the USA. The Romanian case may be also added to the set [Andreescu et al., 2012]. The authors of the aforementioned blueprint propose a typology of university foresight. That typology (Figure 2) and a general framework for university foresight (Figure 3) take into account the possibility of conducting university foresight exercises at the departmental level.

An interesting Polish example of a project run for the benefit of universities is the project entitled "Akademickie Mazowsze 2030" (Academic Mazovia 2030) [Jozwiak et al., 2012]. It was a regional foresight study for the universities of Warsaw and the Mazovia region which aimed at adapting educational courses, models 


\section{Table 1. Foresight Courses Offered by the Universities}

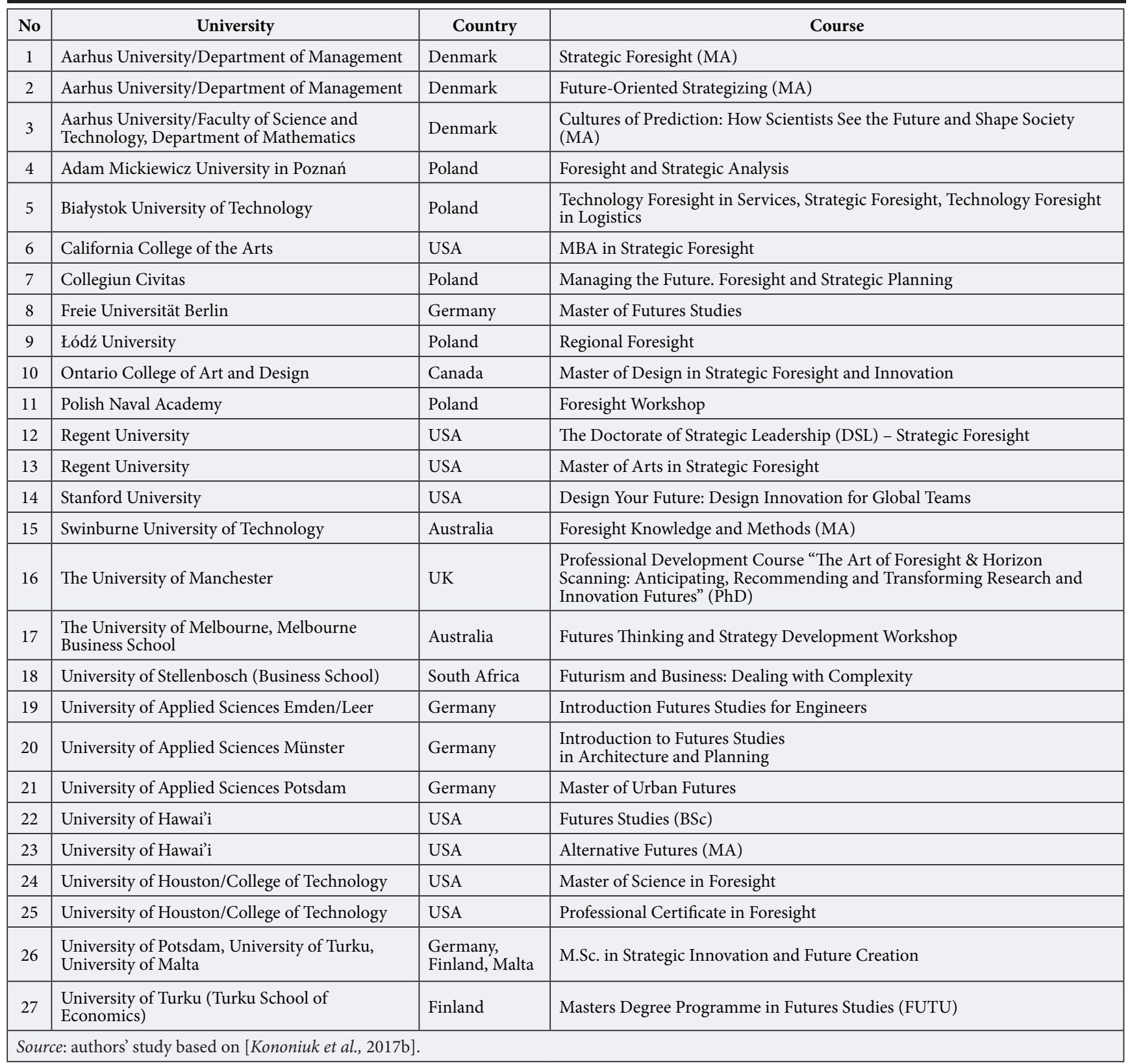

of organization of higher education, and the graduate profile to the real needs of the future labor market. It was the first such project designed by universities involving the academic, business, local government, and student communities at the same time. The program was implemented using foresight methods, including an analysis of scenarios for the development of the region and changes in the Polish economy towards a knowledge-based economy by 2030 . The implementation of the project involved the preparation of three scenarios defining the future of Warsaw and Mazovia higher education institutions. The results obtained were subject to widespread social consultations. As part of the project, discussion panels were organized with the participation of representatives of local government, the business community, and students.

\section{Characteristics of the Faculty of Engineering Management (FEM)}

The Faculty of Engineering Management (FEM) is one of seven faculties at the Bialystok University of Technology. Without a doubt it is a key department given that it has nearly 1,800 students and employs 107 academic lecturers. The faculty has a varied educational program made up of the courses listed in Table 2.

Additionally, the department's educational offerings also include post-graduate and doctoral studies. The faculty is completely independent and maintains its own premises with modern infrastructure.

FEM must be seen as a dynamically developing organization. Its functioning is dependent upon numerous factors that can be divided into four basic groups: 
Table 2. Educational Programs Offered by the FEM of the Bialystok University

\begin{tabular}{|l|l|}
\hline \multicolumn{1}{|c|}{ Area of specialization } & \multicolumn{1}{c|}{ Graduate degree } \\
\hline Management and production engineering & Bachelor, master \\
\hline Management and service engineering & Engineer \\
\hline Furniture engineering & Engineer \\
\hline Logistics & Engineer, master \\
\hline Management & Bachelor, master \\
\hline Tourism and recreation & Bachelor \\
\hline Source: compiled by the authors. & \\
\hline
\end{tabular}

general factors, relational factors, territorial factors, and internal factors. General factors include the level of socioeconomic development, legislation applied to institutions of higher education as well as trends occurring on the labor market and within the sociocultural sphere. Relational factors encompass relationships with internal stakeholders (students, employees), relationships with external stakeholders (businesses, representatives of the local authorities, the general business environment, and local community), and cooperative relationships (cooperation with other higher learning institutions in Poland and abroad). Territorial factors are also very important. The university's location in northeastern Poland shapes the faculty's areas for cooperation and predetermines its connections with various entities on the basis of being so close to the country's border. Internal factors also have an impact upon the university as an organization. Scientific development and the expansion of skills that make it unique are fundamental priorities. The model of operation applied to Bialystok University of Technology as an organization with a complex structure that has its own internal procedures and specific methods of internal communication are also quite significant and complemented by FEM's varied educational offerings that require employees to have different skills and specialties as well as the proper conditions for their development.

A number and variety of factors determine the specific characteristics of problems and the scope of challenges faced by FEM. Factors that strongly impact the direction of changes at the department include socioeconomic factors. It must be stressed that management, a fundamental part of FEM's educational offering as well as the unique feature that has characterized the department since the 1990's, is still evolving. Portions of the program connected to traditional management have been replaced by ones that account for advances such as computerization, digitalization, and improvements in providing services. Further the transition from management to management engineering has been implemented. Changes in the university's educational program must address not only current trends but must adjust to future trends. The improvement of the department's adaptive abilities is also the result of transformations occurring generally for Polish higher education. Bialystok University of Technology, including FEM, is
Figure 4. Number of Students at FEM of the Bialystok University of Technology between 2010 and 2017

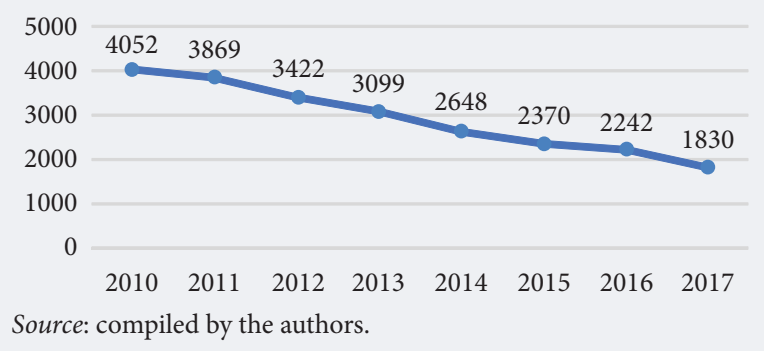

obligated to improve its image as an important educational center that provides both local as well national markets with highly qualified workers. However, maintaining this image is further complicated by the geographical location of the university. Northeastern Poland is seen as one of the slowest developing regions of the country. What is more, changes occurring within higher education have caused the number of students to drop (Figure 4). On the one hand, the reduced access to higher education facilitates more stringent selection processes: only the most talented students are given a chance to continue their education at this level. On the other, the reduced number of students must be balanced with the need to maintain a varied educational program, which requires organizational as well as managerial changes.

The Podlasie Voivodeship borders Belarus and Lithuania, which gives Bialystok University of Technology many opportunities for international cooperation. FEM builds relationships with numerous groups of stakeholders. Students make up the most important target group and come mainly from Podlasie but also from other parts of Poland as well as from Belarus, India, and Ukraine. The faculty's directors see the need to change the way the university is perceived. Locality and regionality are being replaced with internationality. The faculty promotes strong cooperation with foreign universities. Its collaboration with universities from China distinguish it from other schools in Poland.

One of the main challenges that a higher learning facility faces is research development. This does not only concern building intellectual capital but also the creation and development of a research and development profile that is recognized both nationally and abroad. The Faculty of Engineering Management at Bialystok University of Technology is a dynamic organization whose growth depends upon various factors. The need to keep improving its scientific and cooperation potential forces it to remain continually conscious of changes and trends occurring in a variety of areas.

\section{Research Methodology}

The process of building development scenarios for FEM consisted of three successive research tasks. The scheme of the operationalization of the scenario building process is presented in Figure 5. Operationalization 
consisted of the selection of specific research methods within each task and also indicated the expected results for the implementation of the said tasks.

The first research task was to collect the opinions of the faculty's employees on the future of FEM. The future box method was used to accomplish this task [Kononiuk, Glinska, 2015]. Both administrative and academic staff responded on separate pages to the following two questions: (1) What is the purpose of FEM? and (2) How do you imagine FEM in 2035? Then, these answers were put into a specially prepared box.

Another research task consisted of identifying the main driving forces behind the development of the FEM ecosystem. To implement this task, methods such as workshops, brainstorming, STEEPVL analysis, surveys, and prioritization were used. Workshops involve group members' meeting in order to develop a common solution or vision of the future [Nazarko et al., 2011]. The main goal of the workshop is to collect current opinions and specific suggestions about the research area or the method of research implementation [Halicka, 2016]. This method is important in foresight research, both in the initial and final stages, from the point of view of the network of links between participants. The direct exchange of knowledge often unavailable from traditional sources and building consensus in the studied areas is critical [Nazarko et al. 2011; Georghiou et al, 2008]. Brainstorming allows one to gather a large number of ideas in a short period of time. With it, new ideas are generated that are based on free associations by encouraging the team's creative potential and creating an atmosphere conducive to its generation [Nazarko et al. 2011]. In the final part, valuable ideas are analyzed in detail [Popper et al., 2008]. This method is a form of improving group decisions by encouraging the free exchange of opinions and addressing criticism. The creative team should consist of about 10 people [Halicka, 2016]. The STEEPVL analysis allows for the evaluation of external factors of the macroenvironment (Social, Technological, Economic, Ecological, Political, Values, Legal) affecting the development of the relevant technology. It is most often used to identify potential driving forces of scenarios and also allows for the possibility of unprecedented events breaking down trends. The results of the method can be a valuable input material, facilitating the identification of opportunities and threats [Nazarko et al., 2017]. Another method used during the implementation of the second research task are surveys, which allow one to become acquainted with the opinion of selected respondents. Respondents receive and complete previously constructed question-

\section{Figure 5. Scheme Depicting the Operationalisation of the Process of Building Development Scenarios of the FEM}

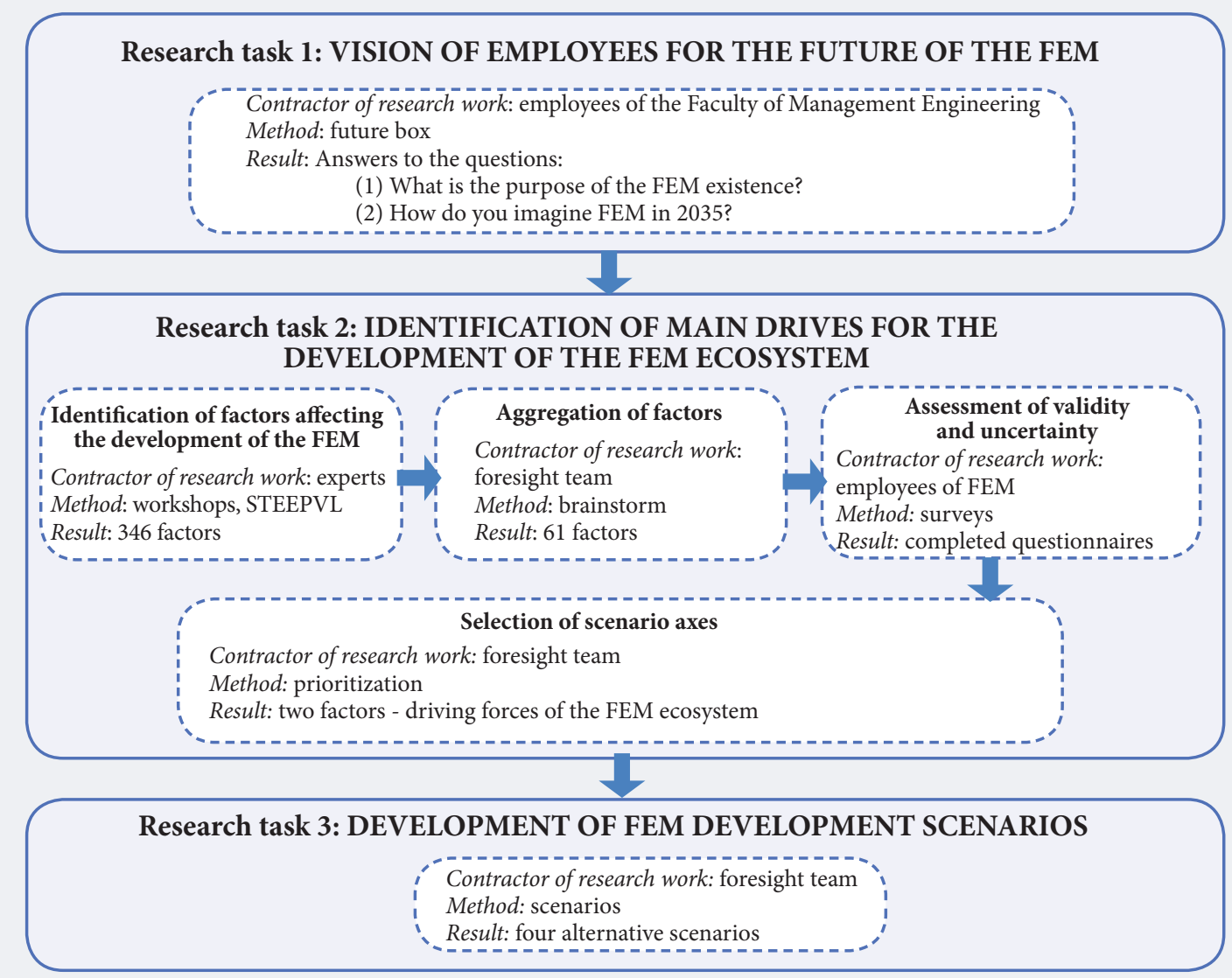

Source: compiled by the authors. 
naires. Surveys are a very good tool for measuring attitudes and views. In such surveys, the technique of the questionnaire is most frequently used. Depending on the method of obtaining data, the surveys can be divided into postal, auditory, and Internet. Most of the surveys are conducted in closed form. Respondents are only asked to indicate the answer, but there are also open questionnaires, where qualitative answers are required, for example in the field of key technological breakthroughs or the formation of socioeconomic trends [Nazarko et al., 2011]. Prioritization was also used to accomplish this task. This method consists of arranging the considered factors on the basis of a set of defined criteria. Most often it consists of the following stages: identifying issues to be prioritized; determining the criteria and weight; appointing a group of experts who will evaluate the data and judgments of other experts; processing and presenting the ranking; and the identification of the most important elements (trends, strategies, policies) [Halicka, 2016]. This method is usually carried out by experts in the field [Georghiou et al., 2008].

The last research task, however, consisted in developing scenarios for the faculty's development. The scenario method was used to accomplish this task. Scenarios reflect a vision of the possible or alternative future for a given phenomenon or possible features of a given future. They rely upon the logical and formal construction of alternative visions of a desired future. Scenarios are not a forecast for a given situation, but rather a simulation of a possible future. So far many different scenario building techniques have been developed. For this reason, the scenario method can be characterized by many different features. For example, it can be a normative (most commonly) method, exploratory, using quantitative and qualitative data, based upon expert analysis or theoretical research, extrapolating current trends, investigating unlikely phenomena, single areas, or very complex structures [Kononiuk, Nazarko, 2014].

\section{Research Findings}

The results obtained by the study were backed by the work of a wide range of stakeholders. The developed research methodology involved the engagement of all FEM employees as well as experts constituting a select group of employees and students, who represented different faculty units, experienced specialists in futures studies, and foresight teams. The study was conducted during December 2017 - May 2018.

To complete the first research task the future box method was used. This method allows one to collect 86 opinions of FEM employees. The questions posed to the participants of the study included two related to the faculty: the purpose of its existence and a vision for the future of FEM in 2035 expressed by respondents. The method ensured anonymity and freedom in expressing opinions.

Among the responses received, there were many positive visions presenting the department as a leading research and teaching center in the region. Some of the responses were related to challenges faced by the department. Results obtained in such a way enabled the faculty directors to rapidly become acquainted with the dilemmas and risks that employees see in their professional environment. Sets of words characterizing each individual opinion were prepared. These sets were prepared by selected members of the foresight team. The words thus obtained were analyzed in terms of the frequency of their occurrence and word clouds were prepared in relation to the two issues addressed: why does FEM exist (Figure 6a) and how do you imagine FEM in 2035 (Figure 6b). The prepared visuals show how FEM employees perceive the department in the context of its purpose and its future.

In the next research task (Figure 2), the identification of the main driving forces for the development of the FEM ecosystem was undertaken, which should be the axes of the scenarios prepared in further proceedings. This included a number of activities related to the

\section{Figure 6. Word Clouds Created as a Result of Aggregation of Statements of FEM Employees}

1) What is the purpose of the FEM existence?

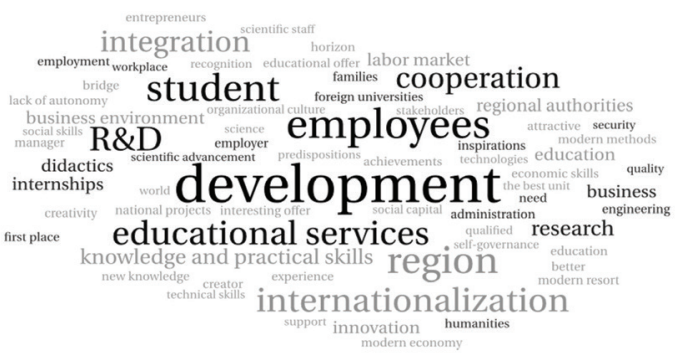

2) How do you imagine FEM in 2035?

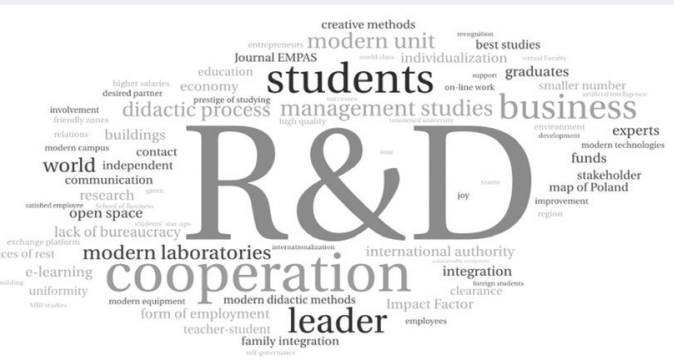




\section{Table 3. List of 61 Aggregated Factors $(n=61)$}

\begin{tabular}{|c|c|c|}
\hline Group & Name of the factor & Acronim \\
\hline \multirow{10}{*}{ SOCIAL } & the ability to continuously develop the FEM ecosystem & S1 \\
\hline & promoting the idea of amiable cooperation between employees & S2 \\
\hline & prestige of the academic teacher profession & S3 \\
\hline & social perception of the value of higher education & S4 \\
\hline & $\begin{array}{l}\text { individualization of the approach to education (according to the profile, student's abilities, work on } \\
\text { strengths) }\end{array}$ & S5 \\
\hline & level of support for the development of each employee by the faculty directors & S6 \\
\hline & openness to cultural diversity & S7 \\
\hline & the importance of interdisciplinary teams & S8 \\
\hline & the ability to work in groups & S9 \\
\hline & balance between direct communication (face to face) and modern forms of ICT-supported communication & S10 \\
\hline \multirow{8}{*}{$\begin{array}{l}\text { TECHNO- } \\
\text { LOGICAL }\end{array}$} & the development of artificial intelligence & T1 \\
\hline & level of Industry 4.0 development in Poland & $\mathrm{T} 2$ \\
\hline & the degree of using a robot assistant in the didactic process & T3 \\
\hline & the impact of technology on interpersonal relationships & T4 \\
\hline & technological availability of FEM for people with disabilities & T5 \\
\hline & personification of technology - the degree of subjectification of technologies in the FEM ecosystem & T6 \\
\hline & degree of using new didactic forms (e.g. augmented reality) & T7 \\
\hline & the role of technology in creating the FEM's brand & T8 \\
\hline \multirow{9}{*}{ ECONOMIC } & level of diversification of financing sources for the universities & EKON1 \\
\hline & businesses' tendency to support university activities & EKON2 \\
\hline & level of co-financing of studies by entrepreneurs (studies ordered) & EKON3 \\
\hline & economic value of education & EKON4 \\
\hline & the level of diversification of FEM services & EKON5 \\
\hline & wage level at universities & EKON6 \\
\hline & coherence of the FEM offerings and smart specializations & EKON7 \\
\hline & the level of adaptation of corporate patterns in university management & EKON8 \\
\hline & the effectiveness of university solutions in the commercialization of research results & EKON9 \\
\hline \multirow{4}{*}{$\begin{array}{l}\text { ECOLOGI- } \\
\text { CAL }\end{array}$} & $\begin{array}{l}\text { the level of utilization of environmentally friendly infrastructure solutions on the FEM campus (e.g., heat } \\
\text { pumps, photovoltaic plants, eco-houses, oxygen bars, renewable energy sources, selective waste collection, } \\
\text { hazardous waste processing) }\end{array}$ & EKOL1 \\
\hline & pro-ecological forms of classes in educational programs (outdoor activities, in the bosom of nature) & EKOL2 \\
\hline & focus on shaping pro-environmental attitudes among citizens & EKOL3 \\
\hline & care for the physical activity of FEM staff and students (e.g. wellness 3.0, yoga, tai-chi, recreation, integration) & EKOL4 \\
\hline \multirow{8}{*}{ POLITICAL } & unification of EU policy in the field of higher education & POL1 \\
\hline & policy of prioritizing selected fields of study and research & POL2 \\
\hline & compliance of the university's strategy with national and regional policy & POL3 \\
\hline & dependence of universities upon particular political interests & POL4 \\
\hline & preferences for less developed regions & POL5 \\
\hline & quality of cooperation between the university and local government & POL6 \\
\hline & the influence of the university upon the development of the region & POL7 \\
\hline & the scope of university support by the local authorities & POL8 \\
\hline \multirow{9}{*}{$\begin{array}{l}\text { VALUE- } \\
\text { RELATED }\end{array}$} & climate for creativity & W1 \\
\hline & level of support for young parents & W2 \\
\hline & participation of employees and students in volunteering & W3 \\
\hline & return to anthropocentrism - "original" interpersonal relations (departure from technocentrism) & W4 \\
\hline & the importance of individuality & W5 \\
\hline & sense of community & W6 \\
\hline & the level of employees' identification with FEM & W7 \\
\hline & openness to changes & W8 \\
\hline & cognitive curiosity & W9 \\
\hline \multirow{13}{*}{ LEGAL } & legal regulations regarding university funding & PR1 \\
\hline & the degree of employee involvement in making decisions regarding FEM (empowerment) & PR2 \\
\hline & participation of entrepreneurs in university governance & PR3 \\
\hline & participation of local government representatives in the university authorities & PR4 \\
\hline & the degree of complexity of the university's organizational structure & PR5 \\
\hline & the level of transparency of legal provisions & PR6 \\
\hline & volatility of legal regulations in the field of higher education & PR7 \\
\hline & the level of overzealous legal attitude of the university administration & PR8 \\
\hline & regional and local development strategies & PR9 \\
\hline & lobbying for the change of laws & PR10 \\
\hline & legal regulations regarding the incubation of start-ups at universities & PR11 \\
\hline & legal regulations in the field of international cooperation & PR12 \\
\hline & priority for the development of technical faculties & PR13 \\
\hline
\end{tabular}




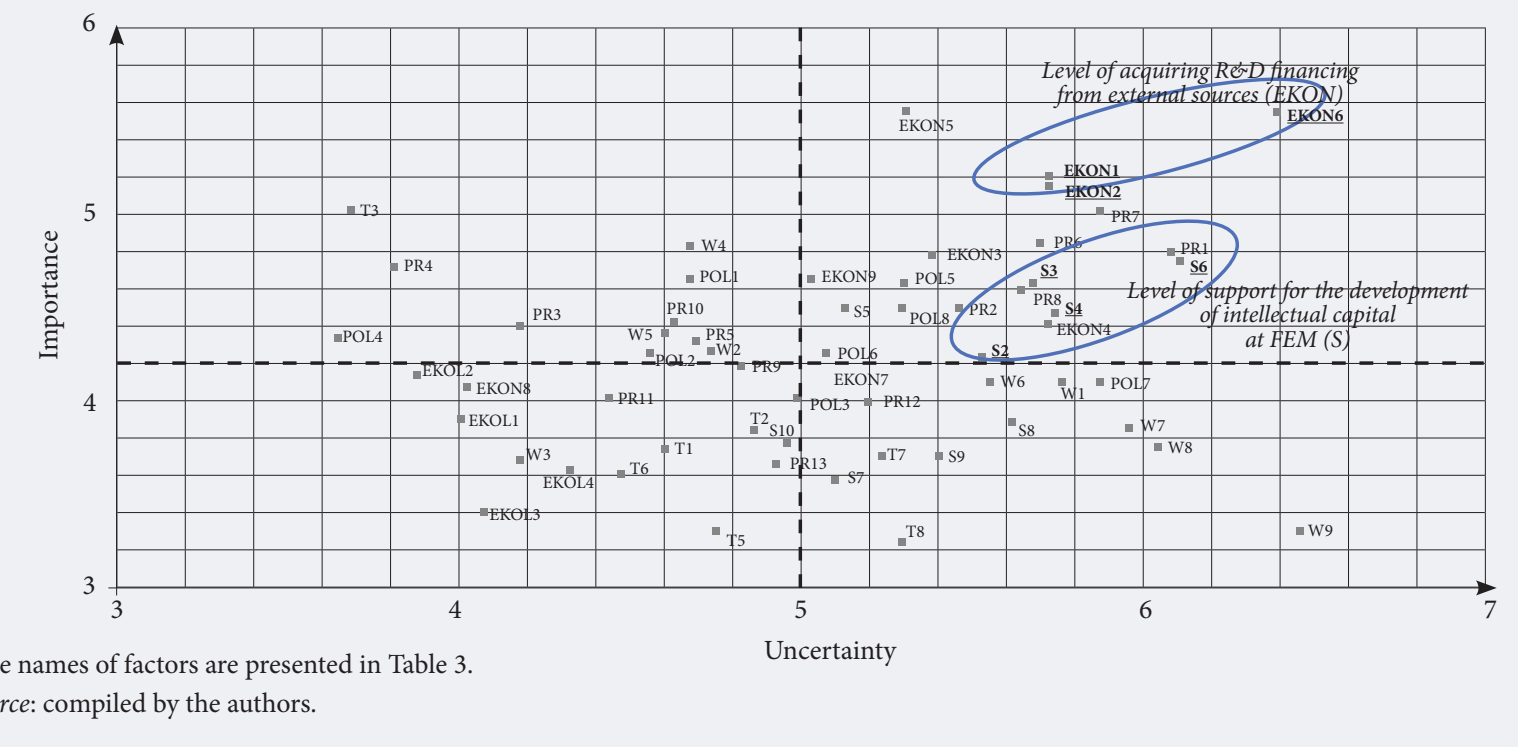

methods used during its implementation. First of all, the factors influencing the development of FEM have been identified. This took place during the workshops carried out at the faculty. Experts were invited to participate in the workshop (selected employees and students representing different units of the department). The meeting was led by foresight team members. The aim of the workshop was to identify development factors using the STEEPVL analysis method. The participants of the workshops were asked: Which factors influence the development of the FEM ecosystem? The workspace was divided into seven areas corresponding to a particular group of factors. After presenting the adopted methodology and STEEPVL analysis to the experts, they were randomly assigned indicated areas. Each of the expert groups was tasked with determining the largest number of factors in a given area within 15 minutes using the brainstorming method. The work of experts was supported by a secretary for the area who was a member of the foresight team. Then, all members of each group, except the secretaries, moved to the next area for another seven minutes and there analyzed the factors generated by the previous group and proposed their additions to the list. This procedure ended when each group expressed itself in each of the seven areas. In this way, within 90 minutes, 32 people generated 346 factors and assigned them to seven areas of STEEPVL analysis.

Next, the foresight team members aggregated the factors obtained during the workshops. The adopted criteria of aggregation were similarity of factors, originality of the proposal, and an analysis of the nature of factors (internal and external factors). The work was carried out using the brainstorming method. As a result, the list of factors was aggregated into 61 groups and separated into the seven STEEPVL analysis areas (the list of factors is given in Table 3).
The aggregated factors were then evaluated in terms of:

- importance for the development of FEM in the period until 2035, applying a rating scale from 1 to 7 , where 1 is the lowest mark and 7 the highest;

- uncertainty for its development in the period until 2035, applying a rating scale from 1 to 7 , where 1 is the lowest uncertainty rating and 7 the highest.

An electronic questionnaire was prepared, which was sent to all employees of FEM. Fully completed questionnaires were obtained from 47 respondents.

The obtained data on the assessment of the importance and uncertainty of factors allowed the foresight team to prioritize factors. Rankings based on arithmetic means determined in both assessment areas were prepared. The obtained averages allowed for placing all factors within an importance/uncertainty area (Figure 7).

Analyzing the data presented in Figure 7, it is clearly visible that the group of the most important factors consists of the economic sphere such as EKON5 - The level of diversification of FEM services and EKON6 Wage level at universities. Moreover, it could be observed that other economic factors such as EKON1 Level of diversification of universities' financing sources, EKON2 - Businesses' tendency to support university activities obtained high marks in the ranking of factors' importance. At the same time, it should be noted that the factors that are the most uncertain according to respondents are EKON6 - Wage level at universities and W9-Cognitive curiosity.

Considering the factors assessed as the most important and characterized by the highest degree of uncertainty, it was necessary to select two factors constituting the driving forces of the FEM ecosystem. The foresight team, analyzing the highest rated and the most uncertain factors, proposed two factors obtained by combin- 


\section{Figure 8. The Layout of the Axis of FEM} Development Scenarios

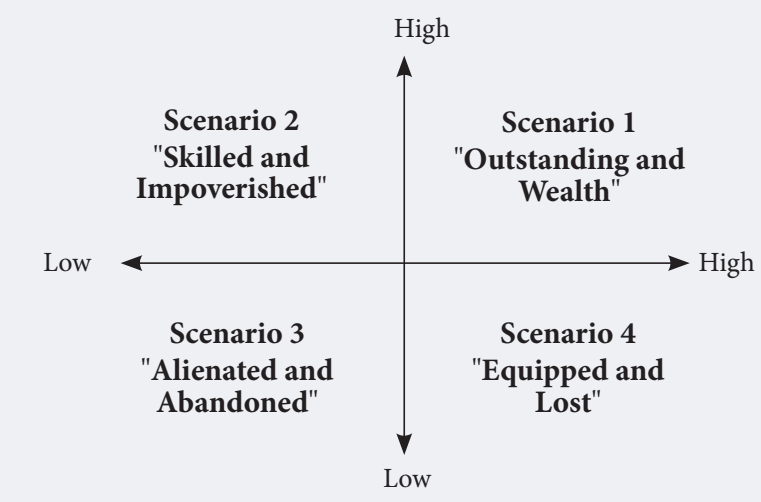

Vertical axis - Level of support for the development of intellectual capital at FEM

Horizontal axis - Level of obtaining financing for R\&D from external sources

Source: compiled by the authors.

ing highly rated factors from the group of economic and social factors.

- Level of acquiring R\&D financing from external sources - including economic factors: EKON1 Level of diversification of universities' financing sources, EKON2 - Businesses' tendency to support university activities, EKON6 - Wage level at universities;

- Level of support for the development of intellectual capital at FEM - including social factors: S2 - Promoting the idea of amiable cooperation between employees, S3 - Prestige of the academic profession, S4 - Social perception of the value of higher education, S6 - Level of support for the development of each employee by faculty directors.

The final task of the research process was to construct the development scenarios for FEM. The research activities carried out in Task 2 made it possible to identify two factors constituting the axes for the development scenarios of the Faculty of Engineering Management. By giving these factors extreme values, the following four future development scenarios were developed (Figure 8):

Scenario 1. High level of support for the development of intellectual capital at FEM and a high level of funding for R\&D from external sources.

Scenario 2. High level of support for the development of intellectual capital at FEM and low level of financing for $\mathrm{R} \& \mathrm{D}$ from external sources.

Scenario 3. Low level of support for the development of intellectual capital at FEM and low level of funding for R\&D from external sources.

Scenario 4. Low level of support for the development of intellectual capital at FEM and a high level of funding for $\mathrm{R} \& \mathrm{D}$ from external sources.
As a result of the brainstorming session, the members of the foresight team proposed the following names for the individual scenarios: S1 - Outstanding and Wealthy; S2 - Skilled and Impoverished; S3 - Alienated and Abandoned; S4 - Equipped and Lost.

The research work carried out throughout the entire process allowed the development of a short description of the characteristics of the four development scenarios for the Faculty of Engineering Management in the period until 2035.

Scenario 1 - Outstanding and Wealthy: There is a positive feedback loop in which both factors drive one another. High intellectual capital allows for the effective acquisition of R\&D funding which, in turn, generates funds for the further development of intellectual capital at the faculty.

Scenario 2 - Skilled and Impoverished: The level of intellectual capital achieved is still too low to effectively raise significant $\mathrm{R} \& \mathrm{D}$ funding, but the faculty/university is consistently investing in raising the quality of intellectual capital. With full commitment to such an action, it may translate into an increase in the ability to raise funding for $\mathrm{R} \& \mathrm{D}$ and thus provide funds for further increasing intellectual capital and a move to Scenario 1. Lack of consistency will lead to Scenario 3.

Scenario 3 - Alienated and Abandoned: In principle, this situation has no way out. The low level of intellectual capital does not allow for effective competition for funds for R\&D, which translates into a lack of funds for the development of intellectual capital. It seems that only external intervention or enormous effort by employees could prevent failure and facilitate a move towards Scenario 2.

Scenario 4 - Equipped and Lost: The level of intellectual capital available allows one to temporarily compete effectively for R\&D funds, but intellectual capital without constant support can quickly decline in quality and transform into scientific craft, which will reduce the effectiveness of competing for R\&D funds and lead to degradation and gradual transition to Scenario 3.

\section{Discussion and Conclusion}

Only universities with a long-term strategy based on alternative visions (as exemplified in this article) will be able to deal with random and unstructured decisions. Only original, variegated strategic concepts allow one to deal with change and avoid the duplication of solutions developed in the past.

The contemporary high level of uncertainty (having both a multi-faceted and multi-definitional character [Magruk, 2016]) in the functioning of both private and public entities such as universities is determined by increasing complexity, their socioeconomic environment, organizational structures of these institutions, their cooperation networks, technological development, and many others factors [Mesjasz, 2014].

The world in which European universities operate has become volatile and unpredictable, therefore, in order to maintain the proper place and role of universities in 
society, higher educaion authorities should be willing to take bolder actions, risk, and experiment [Antonowicz, 2004].

If universities want to be active players on the global academic market, they must move away from the typi$\mathrm{cal}$ administrative forms for shaping their future based on traditional (directed to the inside of the organization [Antonowicz, 2004]), reactionary actions and decisions imposed only by external authorities. One should strive to use unconventional approaches such as foresight methodologies. This research approach allows one to engage others in the creation of visions who will later be beneficiaries of these results. Further it facilitates the unconventional adaptation of institutions so they can act in unstable conditions and cope with new challenges.

The main goal of the article was to present alternative development scenarios of FEM in the period until 2035 based on the original foresight methodology.

A great advantage of the scenario method is realizing that there will be only one future, but there are many paths to reach this future. What path that will be depends upon one's stakeholders, in this case the employees of FEM.

The process of building development scenarios for FEM consisted of three successive research tasks: 1) the vision of employees about the future for FEM; 2) the identification of main drivers for the development of the FEM ecosystem; and 3) the development of FEM development scenarios.

The first research task, using the future box method refers to collecting FEM employee's opinions concerning the future of the department. The results obtained in this way allowed the faculty directors to quickly learn about positive visions as well as dilemmas and threats employees see in their own future professional environment.

The next task was to identify the main driving forces of the FEM ecosystem's development. Driving forces were determined on the basis of the identified and aggregated 346 factors. To implement this task, methods such as workshops, brainstorming, and STEEPVL analysis were used. In this way, the authors of the article confirmed the first hypothesis presenting the relationship between STEEPVL analysis and the informative dimension of the scenario method. The second hypothesis was verified as the group of the most important factors for the development of the FEM ecosystem consists of four factors representing economic sphere. The third hypothesis was rejected given that the most uncertain factors represent economic and value-related groups.

Surveys and prioritization facilitated the assessment of the aggregated factors. Taking into account the factors assessed as the most important and characterized by the highest degree of uncertainty, two were selected. Factors that drive the FEM ecosystem are: 1) the level of acquiring R\&D financing from external sources and 2) the level of support for the development of intellectual capital at FEM. At this point the postulate of J. Ravetz was fulfilled, according to which the selected driving forces should be reasonably independent, but can be interpreted together [Ravetz, 2007].

In the final task, the scenario-axes technique (proposed by S.A., Kl. A. Klooster and M. van Asselt [van Klooster, van Asselt, 2006]) and brainstorming were used to determine (possible, feasible, and desirable) four alternative developmental visions for FEM.

The scenarios created internally coherent, reliable descriptions of the development of events affecting the functioning of FEM. In its (scenarios) narratives, how the current state of reality can transform into possible future states is explained. The most desirable is the first scenario, in which the most valuable resource of FEM is the staff, who are well-rewarded, development-oriented, using a friendly organizational culture and enjoying merit-based prestige in the local community.

Knowledge about less-favorable alternatives is also valuable because it suggests which actions may lead to their realization and indicates specific actions that may lead to their abandonment in favor of the most desirable vision.

The outcomes obtained from this multidimensional analysis were the result of the intergenerational experience of a wide range of stakeholders. The employed research methodology included the involvement of all FEM employees, experts (a select group of employees and students representing various units of the faculty), and a foresight team (experienced specialists in the field of future research).

The use of both bottom-up and top-down expert approaches in foresight methodology is valuable. Bottomup techniques consist of the open participation of the widest possible group of stakeholders. This approach is more unique to foresight processes. It is assumed that participation and social debate are more importantthan the final results [Kononiuk, Magruk, 2008].

\section{References}

Andreescu L., Gheorghiu R., Zulean M., Curaj A. (2012) Systemic Foresight for Romanian Higher Education. European Higher Education at the Crossroads: Between the Bologna Process and National Reforms (eds. A. Curaj, P. Scott, L. Vlasceanu, L. Wilson), Heidelberg, New York, Dordrecht, London: Springer, pp. 995-1017.

Antonowicz D. (2004) W poszukiwaniu nowego paradygmatu zarządzania uniwersytetami w Polsce [In search of a new university management paradigm in Poland]. Nauka i Szkolnictwo Wyższe, vol. 2, no 24, pp. 56-72.

Clark B.R. (1998) Creating Entrepreneurial Universities. Organizational Pathways of Transformation, Oxford, New York: Pergamon Press.

Cunningham S., Ryan Y., Stedman L., Tapsall S., Bagdon K., Flew T., Coaldrake P. (2000) The business of borderless education, Canberra: Department of Education, Training and Youth Affairs.

Curaj A., Michel A., Saritas O., Rossel P., Tuomi I., Miller R. (2010) The FOR-UNI Blueprint. A Blueprint for Organizing Foresight in Universities, Bucharest: The Publishing House of the Romanian Academy. 
Ejdys J. (2013) Regionalny foresight gospodarczy. Scenariusze rozwoju lokalnego województwa mazowieckiego [Regional business information foresight. Scenarios of local development in Mazowieckie Voivodship], Warszawa: Związek Pracodawców Warszawy i Mazowsza.

Ejdys J. (2014) Future oriented strategy for SMEs. Procedia - Social and Behavioral Sciences, vol. 156, pp. 8-12.

Ejdys J., Nazarko Ł. (2014) Foresight gospodarczy - instrumentem orientacji na przyszłość [Economic Foresight - an instrument for future orientation]. Prace Naukowe Uniwersytetu Ekonomicznego we Wrocławiu, vol. 340, pp. 651-664.

Georghiou L., Cassingena Harper J., Keenan M., Miles I., Popper R. (eds.) (2008) The Handbook of Technology Foresight Concepts and Practice, Cheltenham: Edward Elgar.

Halicka K. (2016) Prospektywna analiza technologii - metodologia i procedury badawcze [Prospective analysis of technology - methodology and test procedures], Białystok: Bialystok University of Technology Publishing House.

Hines A., Gary J., Daheim C., van der Laan L. (2017) Building Foresight Capacity: Toward a Foresight Competency Model. World Futures Review, vol. 9, no 3, pp. 123-141.

Jamali D. (2005) Changing management paradigms: Implications for educational institutions. Journal of Management Development, vol. 24, no 2, pp. 104-115.

Jozwiak J., Wielec M., Modrzejewska K. (2012) Foresight „Akademickie Mazowsze 2030”. Raport końcowy [Final report from “Academic Mazovia 2030" foresight project], Warszawa: Politechnika Warszawska, Biuro ds. Rozwoju.

Kononiuk A., Glińska E. (2015) Foresight in a small company. Procedia - Social and Behavioral Sciences, vol. 213, pp. 971-976.

Kononiuk A., Magruk A. (2008) Przegląd metod i technik badawczych stosowanych w programach foresight [Review of research methods and techniques used in foresight programs]. Nauka i Szkolnictwo Wyższe, vol. 2, no 32, pp. 28-40.

Kononiuk A., Nazarko J. (2014) Scenariusze w antycypowaniu i kształtowaniu przyszłości [Scenarios in anticipating and shaping the future], Warszawa: Wolters Kluwer.

Kononiuk A., Sacio-Szymańska A., Gáspár J. (2017a) How do companies envisage the future? Functional foresight approaches. Engineering Management in Production and Services, vol. 9, no 4, pp. 21-33.

Kononiuk A., Gudanowska A., Magruk A., Sacio-Szymańska A., Fantoni G., Trivelli L., Ollenburg S. (2017b) Becoming Future-Oriented Entrepreneurs in Universities and Companies (WP1 report), Brussels: European Commission. Available at: http://futureoriented.eu/wpcontent/uploads/wp1f.pdf, accessed 18.01.2019.

Kwiek M. (2017) Wprowadzenie: Reforma szkolnictwa wyższego w Polsce i jej wyzwania. Jak stopniowa dehermetyzacja systemu prowadzi do jego stratyfikacji [Introduction: Higher education reform in Poland and its challenges. How gradual de-thermization of the system leads to its stratification]. Nauka i Szkolnictwo Wyższe, vol. 2, no 50, pp. 9-38.

Labanauskis R., Ginevičius R. (2017) Role of stakeholders leading to development of higher education services. Engineering Management in Production and Services, vol. 9, no 3, pp. 63-75.

Maassen P. (2008) The Modernisation of European Higher Education. From Governance to Identity. Higher Education Dynamics (eds. A. Amaral, I. Bleiklie, C. Musselin), Heidelberg, New York, Dordrecht, London: Springer.

Magruk A. (2016) Analiza niepewności w złożonych, dynamicznych systemach - przypadek Internetu Rzeczy [Analysis of uncertainty in complex, dynamic systems - the case of the Internet of Things]. Przeglad Organizacji, vol. 1, pp. 53-59.

Mesjasz C. (2014) Nieprzewidywalność środowiska współczesnych organizacji [The unpredictability of the environment of contemporary organizations]. Prace Naukowe Uniwersytetu Ekonomicznego we Wroclawiu / Research Papers of the Wroclaw University of Economics, vol. 366 , pp. $336-346$.

MSHE (2015) 2015) Program Rozwoju Szkolnictwa Wyższego i Nauki na lata 2015-2030 [Ministerial Programme for the Development of Higher Education and Science for the Years 2015-2030], Warszawa: Ministerstwo Nauki i Szkolnictwa Wyższego [Ministry of Science and Higher Education].

Nazarko J. (2013) Regionalny Foresight Gospodarczy. Metodologia i instrumentarium badawcze [Regional Economic Foresight. Methodology and research instruments], Warszawa: Związek Pracodawców Warszawy i Mazowsza.

Nazarko J., Dębkowska K., Ejdys J., Glińska E., Halicka K., Kononiuk A., Olszewska A., Gudanowska A., Magruk A., Nazarko Ł. (2011) Metodologia i procedury badawcze w projekcie Foresight Technologiczny NT for Podlaskie2020: regionalna strategia rozwoju nanotechnologii [The methodology and test procedures in the Technological Foresight NT for Podlaskie 2020 project: Regional strategy for the development of nanotechnology], Białystok: Bialystok University of Technology Publishing House.

Nazarko J., Ejdys J., Halicka K., Nazarko Ł., Kononiuk A., Olszewska A. (2017) Factor Analysis as a Tool Supporting STEEPVL Approach to the Identification of Driving Forces of Technological Innovation. Procedia Engineering, vol. 182, pp. 491-496.

Nazarko J., Glinska U., Kononiuk A., Nazarko L. (2013) Sectoral Foresight in Poland: Thematic and Methodological Analysis. International Journal of Foresight and Innovation Policy, vol. 9, no 1, pp. 19-38.

Paradeise C., Reale E., Bleiklie I., Ferlie E. (eds.) (2009) University Governance. Western European Comparative Perspectives, Heidelberg, New York, Dordrecht, London: Springer.

Peters M.A., Humes W. (2003) Education in the Knowledge Economy. Policy Futures in Education, vol. 1, no 1, pp. 1-19.

Popper R., Keenan M., Miles I., Butter M., Fuenta G.S. (2007) Global Foresight Outlook 2007 (The European Foresight Monitoring Network Report), Brussels: European Commission.

Ravetz J. (2007) Scenario types. Paper presented at the training workshop "Technology Foresight for Practitioners. A Specialised Course on Scenario Building", Prague, 5-8 November.

Shattock M. (2009) Entrepreneurialism in Universities and the Knowledge Economy. Diversification and Organizational Change in European Higher Education, Maidenhead: Open University Press - SRHE.

Stock G. (2008) The current status and the future of universities within society. The University in the Market (eds. L. Engwall, D. Weaire), London: Portland Press, pp. 79-87.

Szczebiot-Knoblauch L. (2013) Instrumenty wykorzystywane do realizacji polityki naukowo-technicznej. Polityka naukowo-techniczna (eds. L. Szczebiot-Knoblauch, W. Lizińska), Olsztyn: Uniwersytet Warmińsko-Mazurski w Olsztynie, pp. 49-69.

Szpilko D. (2015) The Future of Tourism Development in the Podlaskie Voivodeship. Procedia - Social and Behavioral Sciences, vol. 213, pp. 977-984.

Ughetto E., (2007) Foresight as a Triple Helix of Industry, University and Government Relations. Foresight, vol. 9, no 5, pp. 14-22.

UNESCO (1998) Higher Education in the Twenty-first Century Vision and Action (Report for the World Conference on Higher Education, Paris, 5-9 October), Paris: UNESCO.

van Klooster S.A., van Asselt M. (2006) Practising the scenario-axes technique. Futures, vol. 38, pp. 15-30.

van Vught F.A. (1999) Innovative Universities. Tertiary Education and Management, vol. 5, no 4, pp. 347-355.

Whitley R. (2008) Universities as strategic actors: Limitations and variations. The University in the Market (eds. L. Engwall, D. Weaire), London: Portland Press, pp. 23-37. 